\title{
1. Introduction: Uneven development and internet entrepreneurship in Europe
}

Entrepreneurship has awoken in Germany. Everywhere across the country, experienced business people, investment as well as legal professionals, are quitting their secure jobs and are starting internet ventures ... In terms of internet entrepreneurship, Germany is, as yet, still a developing country in comparison to the United States. In America, internet companies, which started in a similarly small way, have already created 2.5 million new, attractive jobs. These companies already today generate 6 per cent of the total GDP of the United States. Germany has only begun to move down this path. But one thing is certain already now: the new entrepreneurial scene is the best thing that has happened in German business for a long time. ${ }^{1}$

Sweden is an ideal starting place for internet entrepreneurs. Here, we develop internet services before moving out to other countries. We have a small population of very advanced internet users. We have to convince a network of only about 30 critical, but opinion-leading journalists of our service. We have to persuade a small, tightly integrated network of private investors. Once we succeed at this, all doors are open. A well-oiled start-up engine is in operation here (Interview, Ahlvarsson, 18 October 1999).

This study explains why Europe, despite initiating a tremendous amount of change in the 1990s, failed to produce independent internet ventures of note. No independent newcomers survived which were able to seriously and in a sustained way challenge American internet ventures or established European telecommunications and media companies. Given the history of uneven development in information technology (IT), this was not surprising. Previous cycles of innovation in IT, which resulted in the development of markets such as the personal computer or data networking, were led or redefined by US ventures such as Apple Computer or Cisco. One prominent reason for the global leadership of the United States in IT innovation was the Silicon Valley region, with its 'entrepreneurial ecosystem' of entrepreneurs, venture capitalists and legal experts (Kenney, 2001, 13).

Yet, this time around, things were supposed to have been different for three reasons. Firstly, internet technology was initially not an exclusive Silicon Valley domain. Before its commercialization, it was an academic 
research network which spanned the globe. Its infrastructure costs were shared, making its use distance-insensitive. The World Wide Web standards, an important prerequisite for the commercialization of the internet, were not created in the United States, but by a British researcher in a Swiss particle physics facility (Berners-Lee, 1999). The international nature of the internet continued to be of importance also after its commercialization. The internet and other global data networks potentially enabled an increase in the international trade of services, giving rise to a 'weightless economy' (Welfens and Jungmittag, 2002, 59; for the term see Quah, 1997).

Secondly, internet innovations were not specific to the IT sector. The internet was a horizontal technology which could be adopted in a diverse set of economic sectors. By linking customers to services and suppliers to manufacturers in 'real time', seamless 'business webs' could be formed which had the potential to increase economic productivity by reducing transaction and inventory costs. ${ }^{2}$ Service industries such as telecommunications and media would be affected strongly by the internet, confirming theories about the convergence of IT, telecommunications and media (Bane et al., 1998).

Finally, in terms of know-how and legal framework, and due to its architecture, barriers to entry for internet services initially were low (see Lessig, 2001). The internet was run with intellectual property, for example UNIX and the TCP/IP standard, which were either 'open' or easily accessible. The internet allowed the global sharing of program codes, enabling the spread of Linux and 'open source' software development, which bypassed software copyrights (Raymond, 1999; Lessig, 2001, 49-72). The architecture of the internet was designed as an 'end-to-end' system, or a 'stupid network', which allowed the addition of innovative applications at its periphery without the requirement of changing the way the network was run (Isenberg, 1997). In fact, every personal computer connected to the internet could host an internet service, a concept that was further developed in so-called P2P technologies (Lessig, 2001, 134-8). The international nature of the internet, horizontal applicability of the technology to numerous economic sectors and the low barriers to entry implied that, this time around, the innovation opportunity was global.

The Achilles' heel of global internet development was a national factor. This factor was telecommunications liberalization and its impact on the local telephone line, the local loop. In the early days of internet commercialization, small and medium-sized enterprises (SMEs) as well as consumers accessed the internet through the local phone line. Due to the dependence of internet access on the local loop, Welfens and Jungmittag correctly called internet access an 'indirectly regulated market' (2002, 93, 94). While multinational enterprises and financial services firms had long 
before the commercialization of the internet used their company-only data networks to realize lower transaction costs or to control supply chains, the particular 'disruptive' opportunity of the internet consisted in the integration of SMEs and consumers into these 'business webs'. ${ }^{3}$ The local loop was an Achilles' heel because it was a crucial aspect of internet development, yet was not a factor which had previously been recognized as a national innovation advantage prior to the commercialization of the internet. The highly advantageous national environment in the United States surrounding the local loop and its predominantly flat-rate pricing was the inadvertent result of a specific historic trajectory of telecommunications liberalization. The fixed-line local loop will remain crucial in the future as well, due to its significance for the development of broadband services.

While the role of the local loop specifically for internet development was not known to policy-makers and regulators in the first half of the 1990s, policy experts and regulators in the US and Europe were very well aware of its importance as a point of control by the former telecommunications monopolist. The telecommunications landscape in Europe was being thoroughly reformed at the time and control of the local loop was a deeply debated issue. Infrastructure competition achieved through alternative, competing networks, such as wireless local loop (WLL) or cable TV, was regarded as advantageous. Yet, the development of alternative infrastructures would take time. An enforced opening of the local loop ('unbundling') was seen as an alternative. In the first half of the 1990s, therefore, decisions regarding telecommunications liberalization and local access were made in Europe which in some countries were detrimental and in other countries advantageous for internet entrepreneurship.

The entrepreneurs of Silicon Valley did not suffer from a 'not invented here' syndrome. The 'entrepreneurial ecosystem' managed to respond swiftly to the internet opportunity. Strong internet ventures were created in the Northern Californian region which used the international reach of the internet to their advantage and achieved global significance in a very short amount of time. Yet, Silicon Valley entrepreneurs were not the only ones which reacted to the unique global opportunity presented by the commercialization of the internet.

Internet entrepreneurship surged in Europe as well. IT growth picked up in Europe, with rates beginning to match those of the United States. ${ }^{4}$ In Germany, the new Frankfurt stock exchange, where numerous internet ventures were listed, seemed to symbolize the birth of a new entrepreneurial culture. From the end of 1999 to the turn of the century, growth rates on the Neuer Markt were identical to those on NASDAQ. In the two months prior to the financial downturn from March 2000, the Neuer Markt had actually grown twice as fast as the booming NASDAQ. ${ }^{5}$ By the end of 2000, 
344 IT, media and telecommunications companies, including 67 internet ventures, had been listed on the new German technology exchange. ${ }^{6}$ While it was surprising that entrepreneurship had apparently reawakened in Germany, it was noteworthy that this reawakening had occurred in telecommunications, media and IT and not in traditional German areas of leadership such as the engineering-based industries. Because of the discrepancy between the success of the Frankfurt technology stock exchange and the historic, disappointing record in IT entrepreneurship, Germany represented the most astounding turnaround story in Europe (see Lehrer, 2000). In other countries, however, entrepreneurship surged as well; 4202 seed and start-up companies received venture capital financing in Europe during the course of 1999. Of these, only 703 ventures were in Germany. ${ }^{7}$

The objective of this research is to explore the hypothesis of a global opportunity for technology innovation delivered via the internet and to explain Europe's entrepreneurial response. ${ }^{8}$ During the 1990s, this promise of global opportunity was contained in a popular vision of a so-called 'New Economy' or a 'Digital Revolution', promoted with missionary fervour by technologists and writers close to technological developments. It was adopted by entrepreneurs and investors. Aspects of this vision were further developed by critical scholarship, especially by sociologists who studied technological change as part of a globalization research agenda. The vision of a New Economy, however, conflicted with contemporary research on innovation and technological development in economics and the political sciences. This research adopted an institutionalist approach and emphasized the existence of distinct local structures determining innovation capacity. Yet, for this very reason, institutionalist scholarship was sceptical vis-à-vis global innovation opportunities which seemed to travel rapidly across borders and eradicated differences among distinct institutional landscapes. The approach taken with this study was to understand the validity of these conflicting visions of technological change by studying actual development in a specific setting. Europe, and especially Germany, seemingly was home to a strong entrepreneurial turnaround in response to global technological opportunity. The apparent entrepreneurial turnaround refers to the number of new ventures appearing in Germany targeting the global internet opportunity. Their appearance in a country marked in previous years by a characteristic lack of entrepreneurial dynamism seemed to validate the popular vision of the New Economy.

In this introductory chapter, the most important themes of this volume will be presented and placed in a theoretical framework. Firstly, the theme of a global innovation opportunity associated with the spread of international data networks will be explored. Practitioners closely involved with IT developments as well as scholars, mostly with a sociology background, 
have extensively described the nature of this New Economy innovation opportunity. The second theme to be discussed is the role of national institutions in promoting or constraining innovation. The central research framework will then be described; based on a novel concept called 'refraction'. Refraction is the distorting effect national institutions have on a global innovation opportunity. The refraction framework is used here as an analytical tool to study the role of national institutions vis-à-vis global shift in the setting of a particular domestic economy, in this case Germany. The main domestic agents and policy arenas in Germany influencing internet development as well as the empirical basis of the study will then be presented. Before moving to the closing comments of this Introduction, the reasons for selecting Germany as the main focus for the study are reviewed. While Germany represented a particularly strong case of an apparent turnaround in response to the global internet opportunity, many of the issues applying to Germany also related to other European countries. In this study, the argument developed in the case of Germany is extended to other countries in Europe (Chapter 7).

\section{GLOBAL OPPORTUNITY AND THE NEW ECONOMY}

A body of work appeared in the 1990s which sought to explain a contemporary, far-reaching and universal shift in the global economy related to digitization and convergence. Convergence of information technology, media and telecommunications was viewed as only the beginning; eventually, convergence would encompass all industries. In some of the literature, the internet manifested this structural shift. Elsewhere, in texts written before the commercialization of the internet, the main concepts were none the less already apparent. These writings became influential guides for contemporary commentators seeking to explain the explosive growth of the internet and the strong entrepreneurial response. It is important to emphasize that this body of work pre-dated the most extreme manifestation of the stock market bubble. It was very different from money-making guides for internet business or airport bestsellers containing internet investment advice - although it probably inadvertently helped contribute to the ideas contained in these texts.

Instead of using the emotionally charged terms 'New Economy' or 'Digital Revolution', the body of work under examination is referred to here as 'network thinking'. Network thinkers were contemporary observers who had privileged access to new developments in IT. Examples of these so-called 'evangelists' were the populist futurist George Gilder (1989, 2000), the technology analyst, activist and investor Esther Dyson (1998) or 
the writer and Wired magazine editor Kevin Kelly (1994, 1998). It is precarious to place very diverse thinkers such as these together in a group, but beginning from a premise of technological change, all predicted a strong social and economic global shift. Technology was seen almost entirely as a positive, liberating force, ushering in new actors, new rules and the demise of the dinosaurs. The differentiating characteristics of the internet discussed at the beginning of this Introduction - the global diffusion of the internet, its horizontal applicability to numerous industries and the low barriers of entry - were recognized and described by these writers, each in their own style and with different emphases.

At the same time as practitioners were promoting network thinking, academics began to concern themselves with similar themes. This body of literature did not at first emerge from within those areas of scholarship which traditionally analysed innovation capacity. Much of this literature was associated with new directions in sociology, such as urban sociology (Sassen, 1996; Castells and Hall, 1994), post-structural economics (Lash and Urry, 1994; Harvey, 1990) or the analysis of the information age (Castells, 1996). As part of a detailed exploration of globalization as a contemporary social shift, sociologists early on addressed the significance of the spread of global data networks in financial services and among industrial multinational enterprises (MNEs). Here, the discussion of social effects in this body of work will remain in the background while emphasis is placed on technology and innovation aspects. Nevertheless, the theme of globalization was such a crucial element to contemporary sociological research that it had to be addressed in this study.

But not only sociologists, also researchers in business strategy concerned themselves with the New Economy. Business strategists sought to explain the rapid growth of new internet ventures. In the words of Cusumano and Yoffie:

For companies competing in the new information economy, the internet is forcing managers and employees to experiment, invest, plan and change their ideas constantly while they are trying to build complex new products and technologies. The internet also requires companies to face the reality that competitive advantage can appear and disappear overnight . . . It was the electronic distribution capability of the internet that allowed Netscape to burst onto the scene in 1994 and, in only a few months, emerge as one of the most serious threats Microsoft had ever faced. This sudden rise to prominence of new companies can and will happen again. $(1998,5)$.

Cusumano and Yoffie emphasized that it took Netscape only three years to reach annual sales of more than half a billion US\$, whereas the software giant Microsoft reached comparable revenues in 14 years $(1998,10)$. The 
basis of this rapid growth was what economists labelled 'network effects'. Network effects appear when the value of a good increases with the number of users. In this environment, users themselves recommend their good to others, leading to rapid distribution. But advantages of network externalities benefiting a single company need not be sustainable; competing companies could also benefit from these effects. Danny Tyson Quah stated this in the following way: 'Superstar successes are in turn replaced, and easily' (1998). And in attempting to benefit from network effects, companies sometimes begin to compete in ways that erode their own established competitive advantages and can lower their profitability (Porter, 2001).

Finally, economists discussed a surprising rise in US productivity and its possible connection to the diffusion of IT in the US economy, leading to lower transaction costs and lower inventory costs (DeLong, 2001; Litan and Rivlin, 2001). While contributing to the understanding of the potentially far-reaching effects of a commercialized and widely available internet, neither business strategists nor economists dwelled on the issue of the global diffusion of the network.

Network thinkers such as Esther Dyson went a step further in describing the consequences of a networked world: 'Analysts and investors wonder who will replace Microsoft the way Microsoft replaced IBM as the information industry's standard. The answer is that no one will: The model of an industry revolving around a central leader will give way to a new decentralised market' $(1998,20)$. Kevin Kelly stated similar thoughts differently: 'The world of the made will soon be like the world of the born: Autonomous, adaptable and creative, but consequently, out of control' $(1994,4)$. The sociologist Manuel Castells wrote: 'The information technology paradigm does not evolve towards its closure as a system, but towards its openness as a multi-edged network' $(1996,65)$. The vision was one of a fluid world marked by constant change which was hazardous to those established players who would not adjust. This vision did not accept national borders, it was by default global.

This volatile environment was deemed to lead to two possible structural consequences. First, the literature seems to suggest that a shift away from established innovation clusters such as Silicon Valley was in progress. Stated differently, a 'Silicon Valleyisation' of the world was occurring. '[The internet is] a powerful tool for integrating local economies into the global economy and for establishing their presence in the world', wrote Dyson $(1998,17)$. Yet, the new centres of innovation need not be greenfield projects, they could also be old cities which assumed new roles in the world economy. Castells contended that 'the largest, old metropolitan areas of the industrialized world are the main centres of innovation and production in innovation technology outside the United States' (1996, 57). Regarding the 
new role of global cities, disagreement existed whether they represented forces of decentralization or centralization. For example, a further influential urban sociologist, Saskia Sassen, showed that the global digital era brought with it concentration in power $(2000,104-12)$. One key theme of most of this work, however, was that the new regions or cities were perceived as having their own dynamics independent of the specific country they happen to be in. Sassen spoke of 'a partial denationalising of national territory' (Sassen, 1996, xii). She emphasized the partial nature of this process because: 'The state itself has been a key agent in the implementation of global processes, and it has emerged quite altered by this participation' (1996, 29).

A second consequence of technological change was perceived to be the transfer of innovation capacity away from the industrial laboratories of large enterprises and research universities, to new entities. These were new ventures but were also enterprising individuals or newly organized, decentralized large corporations (Castells, 1996, 156). New ventures did not need to stay small; they could leverage the network to become large very fast. ${ }^{9}$ International data networks were seen as enablers of new global business processes involving new types of specialized business entities. Related to this were trends towards outsourcing in industry, the increasing value of services as well as an emphasis on cultural production. Castells stated that the economic operating unit in the new global environment was the network itself and ceased to be the firm. The name he assigned to the new organizational form was the 'network enterprise' $(1996,171)$.

Thus, while some work focused on new geographies, such as the appearance of new regions and cities, other work highlighted the emergence of new organizational units such as new ventures. In some of the writings discussed here, these two possible consequences were described as part of a general trend. New geographic regions appeared outside of the established clusters, and they were populated by new ventures. What was more interesting, however, were differences implied by these two perspectives. While it was still very much possible to speak about the importance of unique local determinants specific to the new regions, work that focused on new organizational units could almost completely ignore specific local factors. Kelly stated: 'People will inhabit places, but increasingly the economy inhabits a space' (1998, 95). Castells, citing a fellow sociologist, David Harvey, referred instead to a process of 'time-space compression' (Castells, 1996, 434-7; Harvey, 1990). The second organizational perspective thus represented a radicalization of thinking. It will be argued here that, while this perspective was - especially with hindsight - easily susceptible to refutation due to its naivety, it was also the most consequent description of contemporary technological shift available at that time. It provided one explanation of how 
technological opportunity was able to rapidly move across borders by allowing new ventures to integrate themselves in consumer networks and contribute to new types of seamless and global networked business processes.

On the whole, research within sociology was more critical of technological development and emphasized that while specific regions or new types of enterprises could potentially have immense success, others could face further marginalization (Sassen, 2000, 33-57). These concerns developed into a debate about the 'digital divide'. In contrast, network thinkers were optimistic, believing that technology could reduce global inequality on the whole and provide unique leapfrogging opportunities for new actors. To understand this stance better, it is important to emphasize that what is called network thinking here contained elements of both equality-oriented social democratic thinking as well as elitist, libertarian economic ideas. The New Economy and the Digital Revolution were American inventions, with strong influences from 1960s counterculture and not without jingoistic tendencies as evident in George Gilder's book Microcosm (1989, 344, 346). This set of ideas has early on been masterfully analysed and critiqued in terms of a 'Californian Ideology' (Barbrook and Cameron, 1995). ${ }^{10}$ Cultural critic Mark Dery, moreover, attacked escapist, dangerous tendencies of the 'cyber-hippe worldview' (1996, 21-72). In a sequel to his original book Escape Velocity, he wrote:

In the silicon social Darwinism ostensibly popular with the 33-year old, 81-k earning male who is Wired's typical reader, the evolutionary race goes to the wunderkind small player enshrined in computer industry myth . . . while the unskilled and deskilled masses are stampeded in the mad rush to the millennium (Dery, 1999, 231).

It is a valuable exercise to point out the hidden currents in network thinking, the unstated text in between the lines. This was part of the agenda. Consciously or unconsciously, network thinking was functionally designed for the evangelical purpose to spread ideas of self-fulfilment in an allegedly new network era. This self-fulfilment itself, however, was not escapist in the sense of a social or economic exit. It was linked to creativity and technological innovation in business. In fact, the Digital Revolution was spread over the internet, through bestsellers and periodicals such as Wired magazine, and prepared the ground for the 'investment stories' preached by internet entrepreneurs and investment bankers. This effect was not limited to the United States - network thinking was adopted as a credo for innovation by entrepreneurs all over the world (Waesche, 1999a; Waesche, forthcoming). Yet, network thinking was also a set of ideas born directly out of the technological experience of the 1990s. It was an inseparable aspect of the global entrepreneurial opportunity, its 'ideological framework.' The next section 
will discuss why the central tenants of network thinking, the unique aspects pertaining to network technologies, have to be taken seriously by scholarship.

Network thinking ended at the beginning of the 2000s when the optimism surrounding the internet opportunity proved more and more difficult to uphold. This was due both to the financial downturn as well as to changes in the internet opportunity itself: rising barriers to entry in terms of international leapfrogging, horizontal applicability, the internet's design and legal framework. In his elegy on internet innovation, Lessig wrote:

The story I want to tell is not about the death of innovation generally; it is about the relocation of innovation from the diverse, decentralized internet back to the institutions that policed innovation before. The story is about the bureaucratisation and capture of the innovation process - relocating it back to where it was as a response to the structures originally enabled by the internet itself $(2001,140$, 141).

The innovation opportunity associated with the internet apparently was finite not in terms of geography, but in terms of time.

\section{STRUCTURES AND AGENTS: INSTITUTIONALIST THEORY}

In the previous section, recently occurring technological changes were presented as part of a global structural shift, the so-called New Economy. The structural view of the New Economy suggested that global shift provided new opportunities for a diverse group of new entities such as regional clusters and enterprises. The role of national governments in being able to implement change was seen as severely compromised. Even the new entities favoured by global shift were merely participants; they were not agents driving the change process. Technological change was seen as a powerful, exogenous force.

In this sense, network thinking shared similarities with neo-Marxist theory, which viewed structural change as a constant, driven by very generalized forces such as the accumulation of capital (Wallerstein, 1979, 272; Cox, 1987). Underlying these approaches was an implicit belief in linear progress. A diversity of outcomes caused by the existence of individual agent choice was purposely excluded from the model. As Geoffrey Hodgson pointed out, however, the neo-Marxist approach could account for structural change but not for the simultaneous existence of different types of capitalism; in Hodgson's words, 'impurities' within capitalism (1996, 416-9). 
This leads to a further explanation which could be used to explain internet development internationally, which meshes agent-induced change into a structural framework. Here, actors such as national governments were both contributors to structural shifts as well as captured within structures. Outcomes were not fixed. Therefore, change opportunities existed, but they were scattered and refracted. To emphasize the less deterministic and less universal use of the structure concept (compared to Marxist work), the term 'institution' is used. The term has been defined as: 'The rules of the game in a society or, more formally, the humanly devised constraints that shape human interaction' (North, 1990, 3).

As is evident from this definition, there is little distinction in institutionalist research between the realm of politics and economics. In fact, it is this blurring of distinctions which characterized 'new' political economy (Gamble, 1995) as well as 'new' economic history (Wischermann, 1993). Economics itself became broader and had, in the words of Mancur Olson, 'expand[ed] into the suburbs ' (Olson and Kähkönen, 2000, 1). According to Peter Hall, a political economist, institutions play a role in: 'the definition and articulation of interests, the dissemination of ideas, the construction of the market behaviour and the determination of policy' $(1986,5)$. In this view, the market is itself an institution, as not only Hall but also the economist Geoffrey Hodgson and the economic historian Douglass C. North would point out (Hall, 1986, 12; Ash et al., 1994, 9; Wischermann, 1993, 250). Especially, financial markets as institutions seem to play a critical role in fusing the political and the economic (Zysman, 1983, 7, 8). This approach to the role of institutions can be summarized with the phrase 'institutions do matter' and can be found in the disciplines of economics, economic history and political economy.

Broadly, two approaches of institutionalism can be differentiated. Historical institutionalism explains differences in structures through historic development (North, 1990). The key concept here is that present structures were influenced by historic development. Institutions thus follow certain trajectories; this concept is called 'path dependence' (Hill and Deeds, 1996, 435-7). Related to this, institutions tend to be 'sticky'; they define actor relationships most of the time and can preserve these over longer terms. This flavour of institutionalist scholarship is popular with scholars describing technological change because it allows insight into the origins of sustainable innovative capacity. The second approach, rational choice institutionalism, focuses on structures and information asymmetries at a specific period in time (Milner, 1997; see also Garrett and Lange, 1996, 49). Game theory is used as an analytical device to discuss rational choices among different policy options. This is only a rough categorization; institutionalist theory has been applied to a wide variety of research agendas. 
The similarities of the institutionalist approaches found in these disciplines, in emphasizing the role of agents and their relationship to institutional structures, are more important for this study than their differences (discussed in Steinmo et al., 1992, 8).

In discussing actual cases, however, the reconciliation between agent choice and institutional structure is not straightforward in instituionalist scholarship. As Helen Milner has pointed out, 'new institutionalism' has often tended to emphasize institutional constraints over actor-induced innovation of institutional structures (1997, 14-17). Yet, the theory allows for the possibility of significant agent-induced structural change. In the classic object of study for technological innovation, the Industrial Revolution, a radical sea change occurred, resulting in institutional changes brought about by specific actors. Technological innovation occurred in combination with a broad set of parallel social and economic changes. Yet, even during and after the Industrial Revolution, older institutional structures continued to exist and exert influence (Landes, 1969). Thus, a tension between actor-centric and structure-centric explanations is fundamental to institutionalist thought. There is no universal outcome to this tension, which is one of the strengths of the institutionalist approach. Yet, this also necessitates a close appreciation of historic detail; the possibility of unique social and economic trajectories needs to be taken seriously by scholarship.

Major contributions to institutionalist theory originally emerged out of the detailed study of technological change by economic historians such as Douglass North. Economic historians examining the history of innovation have found technological explanations alone are insufficient as an explanatory framework and have extended the discussion to a wide variety of political and cultural factors. Economic history therefore frequently approaches technological change by identifying groups resisting innovation and those promoting it. But interaction always occurs within a given historical institutional environment market by path dependence (Olson and Kähkönen, 2000, 13). Therefore, the inventive achievements of the entrepreneur are not sufficient alone to bring about change, despite the popular prevalence of what Mancur Olson calls the 'parable of the self-made entrepreneur' (Olson, 2000, 183). ${ }^{11}$

The guiding premise of new institutional economic history regarding technological innovation can be summarized in the following way:

But the market is by no means the only way of aggregating the gains and losses from adopting an innovation; a variety of regulatory or political processes can be used to determine whether an innovation is to be adopted, and each will in general aggregate the gains and losses differently and thus will often come up with different answers about whether an innovation should be adopted. ${ }^{12}$ 
Moreover, the timing of change has been studied. Economic historians such as Joel Mokyr have examined occasional, disruptive periods of intensive innovation activity which may be accompanied by significant economic and political changes. These periods are called 'punctuated equilibria', leaning on lessons from modern evolutionary biology (2000, 69-72). These periods can be triggered by events not directly related to technology, such as changes in the social environment. An example was the Glorious Revolution of 1688 in Britain, which was an important precursor to the technological breakthroughs of the eighteenth century (Mokyr, 1990, 298, 299).

A further body of work studying innovative capacity which is closely related to economic history in its approach is national innovation systems (Nelson, 1993) and sectoral innovation systems research (Mowery and Nelson, 1999a). This research approach focuses on the impact of institutional factors on the innovation capacity of contemporary economies and emphasizes, for example, differences in national educational systems. This work also highlights differences among distinct types of technologies and industrial sectors, as does economic history. Systems technologies such as electrical systems or aeronautics, for example, require a complex combination of improvements while other technologies do not (Nelson and Rosenberg, 1993, 13-15).

A related direction of innovation research can be labelled the 'resourcebased' view found in management studies and within a research agenda called 'evolutionary economics'. Here, attempts are made to describe the origins of innovation within the firm and pry open the 'black box'. Firms are seen as independent agents capable of change. Their potential for innovation is limited by their internal resources - their management capabilities, for instance. These resources are mostly intangible; Nelson and Winter therefore call them 'routines' (1982). In this view, firm strategy should focus not on pursuits such as erecting entry-barriers but on nurturing, accumulating and deploying resources (Penrose, 1966; Foss, 1996, 1). Thus, routines can be compared directly to institutional linkages, the habits found in institutionalist scholarship. They exhibit path dependency but can, at times, be changed accidentally (mutations) or purposefully through individual agency.

A final, influential body of work discussing innovative capacity is not directly related to institutional scholarship. Industry organisation research and the 'industrial cluster'-based theory is closely associated with Michael E. Porter (1990). ${ }^{13}$ While the cluster-based theory of national industrial competitive advantage does not explain the rise of a new industry or a new technology, it is an extremely instructive research tool for comparative work in innovative capacity. The objective of this research is to identify 
country-specific or region-specific factors that lead to international competitive success. Porter focuses on microeconomic factors such as local demand conditions, regional industry structure and the intensity of local competition. Advanced local demand structures, for example, allow enterprises to develop products and services which excel in international competition. However, the industry cluster is a mostly static framework. Porter's recent work shows how change occurs within these clusters, yet he still relates it to largely exogenous factors such as technological change, changes in demand structures and an ebbing of domestic rivalry (Foss, 1996, 4, 9-12; Porter, 1990, 166-73).

Institutionalist research has come a long way towards understanding the forces driving innovation. It is viewed not as an exogenous force, but as a capability which can be nurtured by policy-makers, entrepreneurs and managers. Yet, in different historic periods, innovation capability itself differs and industry structure evolves (Mowery and Nelson, 1999b, 370-75). Because of the possibility of significant change, the danger implicit to active, sectoral technology policy is that policy may very well be promoting the 'wrong' players. Whereas chemical-pharmaceutical and electrical innovations at the turn of the twentieth century emerged to an extent out of the industrial research laboratories of large concerns and the research university, IT innovations at the turn of the twenty-first century may instead have favoured different organizational entities. ${ }^{14}$ Innovation opportunities need to be understood not in general, but in specific terms related to the sector and the time period, and this has deep implications for domestic policy intending to promote national innovative capacity. ${ }^{15}$ The institutional approach, therefore, is not incompatible with concepts of change proposed by network thinkers. Institutionalist thought does not rule out the possibility of transformation wrought by technological innovation; it does, however, emphasize that this happens only rarely and that it is accompanied and influenced by political and social changes.

\section{SUSTAINED VARIETY VERSUS GLOBAL CONVERGENCE}

The previous section explained the view that 'institutions do matter'. The institutionalist approach was developed within political economy and economic history as an analytical tool to account for subtle differences in diverging paths of developments during the Industrial Revolution and the twentieth century. Network thinking emerged out of the experience with information technologies in the 1990s. Differences existed in between the two views in terms of agency. Independent agent-influenced change is pos- 
sible in institutionalist analysis, although continuity is more usual (Steinmo et al., 1992, 15). Government bodies involved in a catching-up process of national competitiveness can purposefully strive to make improvements in their institutional structure; their success usually depends, however, on whether they can 'get it right' and, among other things, the participation of other agents in the financial establishment. ${ }^{16}$ Technological change is endogenous and can be explained through the interplay between agents and structures. All this stands in strong contrast to much of network thinking, under which technological change is exogenous. ${ }^{17}$ Change is not independent actor induced, but deterministic, thus bearing ironic similarities to neo-Marxist views of structural change.

Both views have incorporated evolutionary models. Institutionalists such as Hodgson have pointed out that evolutionary change is driven by the necessary existence of diversity among institutional arrangements (Hodgson, 1996, 417). The impurities of capitalism trigger change. In the network thinking of Kelly, evolution and diversity are also stressed. They are based, however, on what Hodgson would call a populist, Darwinian interpretation of evolution. In contrast, recent biological studies emphasize the fact that evolution does not always guarantee the 'survival of the fittest.' In fact, the criteria of fitness very much depends on the current evolutionary landscape and is continually subject to change (Hodgson, 1994a, 209, 210). A domestic institutional environment which has been successful as an export-based industrial economy does not have to be suited to perform successfully in a post-industrial world. 'Populist' interpretations of evolution, therefore, assume the world is static and a certain winner type remains a winner for all time. The approaches utilized in this study, institutionalist political economy and economics, evolutionary economics and the resource-based view in management studies, emphasize the necessity to examine not only corporate successes, but also failures (see Schendel, 1996a, 1). Firms or even whole nation states surviving for many years on the brink of bankruptcy may contain resources that lead to success in another environment.

The main concepts of network thinking are summarized in Table 1.1 where they are compared to institutionalist scholarship. The two opposing lines of network and institutionalist thinking should not be overemphasized. Their differences reflected their very distinct objectives. To a certain extent, they echoed the contrasting views on technological change found within the work of Max Weber and the early work of Joseph Schumpeter. In fact, juxtaposing the two scholars has been a popular academic activity (Hamilton, 1996; Galambos, 1996). Interestingly, the work of the German sociologist resurfaces in the technology perspective of economists, management theorists and economic historians, whereas sociologists and popular 
Table 1.1. Differences in network thinking and institutionalist views

\begin{tabular}{|c|c|c|}
\hline & Networks matter & Institutions matter \\
\hline $\begin{array}{l}\text { Process of } \\
\text { change }\end{array}$ & $\begin{array}{l}\text { Deterministic global structural } \\
\text { change. Schumpeterian } \\
\text { creative destruction. }\end{array}$ & $\begin{array}{l}\text { Refracted and scattered change } \\
\text { taking place within institutional } \\
\text { constraints. Path dependence. } \\
\text { Stickiness. }\end{array}$ \\
\hline Actors & $\begin{array}{l}\text { New actors and regions are } \\
\text { favoured by change, but } \\
\text { they are not driving it. }\end{array}$ & $\begin{array}{l}\text { Firms, national governments, } \\
\text { lobbying groups, regions, } \\
\text { institutions of all types. }\end{array}$ \\
\hline $\begin{array}{l}\text { Possibility of } \\
\text { individual } \\
\text { agency }\end{array}$ & None. & $\begin{array}{l}\text { Difficult but possible within } \\
\text { institutional constraints. Most } \\
\text { probable through influence over } \\
\text { powerful central institutions, } \\
\text { especially financial institutions. } \\
\text { Contest between groups resisting } \\
\text { and groups promoting } \\
\text { innovation. }\end{array}$ \\
\hline $\begin{array}{l}\text { Type of } \\
\text { intercon- } \\
\text { nections }\end{array}$ & $\begin{array}{l}\text { Open computer networks. } \\
\text { Low barriers to entry. }\end{array}$ & $\begin{array}{l}\text { Historically formed institutional } \\
\text { relationships. }\end{array}$ \\
\hline $\begin{array}{l}\text { Technological } \\
\text { innovation }\end{array}$ & Exogenous. & $\begin{array}{l}\text { Incremental. Path dependent. } \\
\text { Endogenous. }\end{array}$ \\
\hline $\begin{array}{l}\text { Result of } \\
\text { change }\end{array}$ & $\begin{array}{l}\text { Global convergence and } \\
\text { equality of opportunity. } \\
\text { Less political and economic } \\
\text { hierarchy. 'Dinosaurs' left } \\
\text { behind. New actors emerge } \\
\text { as winners. 'Leapfrogging' } \\
\text { by new regions or cities. }\end{array}$ & $\begin{array}{l}\text { Sustained variety. All } \\
\text { institutions involved in } \\
\text { incremental change. New roles } \\
\text { for 'old' actors. }\end{array}$ \\
\hline
\end{tabular}

network thinkers refer to the Austrian economist. These two great thinkers will be returned to at the end of this volume.

The approach taken here is to focus on a specific, large national economy where institutional factors influencing information technology innovation initially seemed especially constraining but where, nevertheless, a significant entrepreneurial wave did seem to materialize, apparently in response to outside global developments. This economy could not be the United States, since as the originator of the internet wave, it did not contain the potential conflict between domestic institutions and a global technology opportunity arriving from the outside. And it is exactly this conflict 
between inside, domestic agents acting within the constraints of domestic structures, and outside, global structural change, which is the focus of the book. In Germany, this conflict seemed especially severe. Many Germans and observers in other countries had almost completely forsaken the thought that Germany could achieve prominence in IT and participate in global IT innovation when, apparently, a significant wave of entrepreneurship in IT suddenly did materialize in Germany.

This book evaluates in what specific ways global technology interacts with national institutions. To do so, a framework for the study of crossborder innovation is introduced, based on the concept of 'refraction'. Refraction is the distorting effect national institutions have on a global innovation opportunity. Change agents, for example new ventures, respond not directly to global shifts but to their refracted state. The refraction effect can either magnify or reduce opportunity for new international ventures and therefore directs the path of development of new ventures in a specific country. Other actors, for example, government bodies or established enterprises, also act within this framework. Refraction is a hypothetical framework; the assumption made is that both global structural change as well as domestic institutional constraints can co-exist. In fact, the concept inversely measures the strength of global technological change. The stronger the refraction effect is, the weaker is global shift.

The refraction framework is closely indebted to work in international political economy (IPE). IPE began as a field of international relations (IR) which can be defined through its object of research, the world economy and the role of international and domestic institutions in the world economy. IPE from the early 1970s onwards wrestled with the concept of systemic changes in the world economy (see Katzenstein et al., 1999b, 15-17). Much of the debate was focused on the role of multinational enterprises (MNEs). A debate emerged between scholars emphasizing global change and the retreat of the state (Stopford, Strange and Henley, 1991) and those pointing to the continuing role of the nation state (Krasner, 1994, 15; see also Inayatullah, 1997). In the United States, this debate has been seen as a contest between so-called liberal and realist camps. In Europe, and more recently in the US (Gilpin, 2001), the discussion was less focused on the liberal-realist contest and led to original, combinatory research approaches. Sally, for example, began with an IPE inquiry to carry out what he called a micro-political examination of 'embeddedness' (Sally, 1994; 1995). Embeddedness described the extent to which multinational enterprises (MNEs) were rooted in their home countries. The concept is similar to refraction, but the analytical emphasis is different. The objective when measuring embeddedness is understanding home country linkages of global enterprises abroad. The focus when measuring refraction is the 
distorting effect of national institutions on globally oriented enterprises at home. Most importantly, the refraction concept attempts to build a makeshift bridge between network thinking and institutional scholarship for analytical purposes.

Within IPE, the refraction framework reflects a current debate surrounding the resilience of national institution vis-à-vis internationalization. Increases in international economic interaction in recent years have been linked to domestic political instability, 'political entrepreneurship' and domestic institutional reforms (Milner and Keohane, 1996, 16-20). However, while technology is seen as a key influence in globalization, IPE research has not explicitly explored the relationship of power and technological innovation. This is why the refraction framework has borrowed from different sources: sociological studies of globalization, and what is called here 'network thinking' - contemporary popular accounts of technological opportunities wrought by global networks - as well as institutionalist scholarship on the history of technology and innovation. ${ }^{18}$

The concept of refraction is put to active use to study the development of the internet in Europe. The interplay of global technology and specific domestic agents in specific domestic policy arenas was analysed through a close qualitative and quantitative examination of the development of new internet ventures in European countries, especially in Germany. The resource-based view on enterprise development was drawn upon to gain a better understanding of how different types of external factors influence the development of company resources at an early stage of formation. Some specific national factors examined here were local demand structures, the promotion of risk capital and the legal and regulatory framework relating to entrepreneurship. Economic history and research in national industrial competitive advantage, especially the cluster-based theory, were consulted as well, and the determinants are linked to two policy arenas, telecommunications liberalization and research policy.

The apparent blurring here of national determinants 'external' to the firm and resources 'internal' to the firm was purposeful and reflects the contention that they are different perspectives of the same phenomena. ${ }^{19}$ The new ventures themselves are, metaphorically, the vessel in which different influences make themselves felt. The measure of success is 'industrial leadership' of the start-ups as a group and not solely of one exceptional venture. Mowery and Nelson define the term as 'being ahead of one's competitors in production or process technology, or in production and marketing, [giving] firms an advantage in world markets' (1999b, 2). Mowery and Nelson differentiate the term industrial leadership from the term 'competitive advantage', which may confuse because it is often used to refer to the success of specific firms. It is important to reiterate that some network 
thinkers explicitly stated that leadership in a New Economy is not sustainable and this view contradicts, to a certain extent, the concept of industrial leadership which is used here as a yardstick. However, what is attempted here with the refraction framework is to find common ground in comparing two very different sets of ideas; establishing this common ground may at times be problematic.

The author is aware that the task taken on here is complex. What is attempted in the study appears here to be very abstract. This is not the case. The focus on enterprise-level quantitative and qualitative data in Europe and specifically in Germany serves as a backbone of this effort, allowing research from different sources as well as insight from different theories to be incorporated in a structured way. In addition, the study is organized around a limited number of specific domestic agents and specific policy arenas.

\section{THREE DOMESTIC AGENTS AND TWO POLICY ARENAS}

To understand how domestic institutional structures operate, it is necessary to adopt a micro-political, detailed perspective on individual agents and policy arenas (see, for example, Sally, 1995, 206, 207). Different types of agents, not simply government bodies, contribute to policy decisions. To describe the complex structure policy decisions are typically made in, Helen Milner uses the term 'polyarchy'. Polyarchy refers to power-sharing arrangements among domestic groups. The distribution of power in given historic situations is always more complex than in a simplistic hierarchy, even in what appears on the surface to be extremely hierarchical, totalitarian regimes (Milner, 1997, 11-14).

Three types of domestic agents and two policy arenas were regarded as being especially relevant for this study of Europe. The three domestic agents in the polyarchy were national government bodies, the former public telecommunications operators (PTOs) and young, innovative internet ventures. The policy arenas were telecommunications policy, which influenced internet access and demand, and national technology policy, especially the promotion of venture capital.

What were the reasons for selecting these agents and policy arenas? National government, for example, needed to be differentiated from other state actors such as regions and supranational policy bodies, both of which played an increasingly strong role in Europe. In the case of Germany, at least three regions, Baden-Württemberg, the city-state of Hamburg as well as Bavaria, were very active in subsidizing small firms in 
IT and telecommunications. The European Commission was also engaged in different initiatives to support small firms in this area, some programmes were being carried out with other G7 or G8 members. National government was, therefore, not the only actor involved in competitiveness policy directed at internet ventures. National policy-makers were not even necessarily the most active; regional and supranational incentives both specifically tended to target individual firms or groups of firms with support packages including network access subsidies or free consulting services. One of the reasons why national government is central to this study, however, is because of its role in telecommunications liberalization, the Achilles' heel of global internet development. The contention made here is that this national policy arena, by influencing the demand structure for internet services, was the crucial determinant for new venture success on an international basis. It was thus a strong contributor to refraction. When we shift our emphasis away from internet development to other industries or other historic periods, however, the national perspective may be misleading (Mowery and Nelson, 1999b, 366-70; Nelson and Rosenberg, 1993, 15-18).

When speaking of national government, this study is referring to different policy bodies which did not always have compatible interests. National government policy almost always was the result of intense internal negotiation, causing policy inconsistencies and contradictions. In the case of Germany, three specific ministries were of greatest interest. These three were the Ministries of Finance, of Economics, and of Science and Education. The democratic representative bodies also played a role, as well as intermediary organizations placed in-between the private and public sectors. One such intermediary, parapublic organization was a very important public-private SME financing institution, the Deutsche Ausgleichsbank. ${ }^{20}$ These different bodies were central in framing both telecommunications policy, and innovation and technology policy - which included a programme to promote venture capital. Scholars analysing the German policymaking process in comparative studies have classified German politics as 'corporatist'. In Chapter 4, this term will be examined for its usefulness in understanding the decision-making process among different national policy groups.

The second agent to be introduced here was closely linked to national government. However, the PTOs needed to be understood as independent economic and political agents. Their interests were shaped by a unique historical trajectory, which cannot simply be equated to a purported unified government interest. In the case of Germany, six historical themes stand out; they have shaped today's Deutsche Telekom AG (DTAG). They are the universal telephone system, the technological capabilities of DTAG, the 
former monopolist's involvement in the roll-out of a modern telecommunications infrastructure in the so-called New German States, the privatization and stock market listing of the company, its desired transformation from a domestic to a global player, and its response to the actions of the regulatory authority after liberalization in $1998 .{ }^{21}$ Through its nearuniversal ownership of all means of consumer internet access before liberalization, it is not possible to understand the development of internet services in Germany without analysing the role of Deutsche Telekom and its historically determined interests.

The final type of agent to be introduced here is the new internet venture. While in the 1990s only a limited amount of academic research was carried out on internet start-ups, scholarly attention began in the 1980s to be focused in general on the innovative capacity of small and medium-sized enterprises (SMEs) (Rothwell and Zegveld, 1982; Curran et al. 1986; Haskins, 1986; Klandt, 1987; Bannock and Albach, 1991; Mullineux, 1994; Baker, 1996). The innovation capacity of small and medium-sized enterprises has been discussed with German cases as well (Koschatzky, 1997b; Harhoff, 1997). Scholarly efforts initially were directed at showing that small firms can indeed be innovators. Traditionally, dominant views, also in political economy, emphasized the power of Chandlerian large firms in terms of market domination and innovative potential. ${ }^{22}$ Work on SMEs has often been accompanied by research exploring the role of regional networks for SME development. One of the best-known of these efforts is AnnaLee Saxenian's work which explores the advantages of Silicon Valley over Route 128 in Massachusetts (1994). In Europe, it was hoped that SME growth would be a solution to unemployment problems. This work has been accompanied by parallel developments in government programmes targeted at the needs of SMEs. Aspects of this body of scholarship were very helpful here, especially analysis of the symbiotic relationships between large and small firms (Rothwell, 1986) and the significance of regional networks of large and small firms. German research, specifically, was invaluable to provide insight into the effects of research policy targeting SMEs in Germany. However, the usefulness of SME research for this study is restricted, due to the focus of much of this work on older industries, not the role of new types of ventures in areas undergoing rapid technological change and supported by venture capital, such as software development or internet services. Perhaps this is the reason why a few of the SME studies cited above came to the conclusion that SMEs are well suited to primary inventions but do not have the financial resources to bring these to the market (Carnoy et al., 1993, 8; Rothwell, 1986, 134, 135).

The reason research on SMEs has not delved into the role of new ventures in IT, media and telecommunications innovation is obvious: much of 
SME research predates these development. For this study, recent work examining the role of small firms in Silicon Valley was important to gain comparative insight. Serious work in business strategy on Silicon Valley firms emphasized both the equally innovative role of specialized 'pure play' small network players and the support given to them by experienced venture capitalists and private investors (for example, Cusumano and Yoffie, 1998). Steven S. Cohen and Gary Fields have re-emphasized the regional advantages of the success-driven, networked and highly diverse environment of Silicon Valley (1999). But regional differentiating factors associated with Silicon Valley were not the only reasons why a small number of US internet ventures managed to achieve a sustainable global presence. ${ }^{23}$ As in Germany, one national policy arena was especially important for the development of the internet in the United States, namely, telecommunications policy influencing local demand structures for internet services.

Business press articles discussing the contemporary development of the internet repeatedly pointed out the importance of internet access as one crucial country-level institutional factor. As such, the identification of this factor is not unique to this study. These popular accounts, however, fail to examine in what way forward linkages from the telecommunications industry influenced internet entrepreneurship. The firm-level analysis combined with a study of institutional reform provided the right type of approach for this concern.

\section{THE CASE FOR GERMANY}

Germany excels at, and is stuck in, mid-level technologies - great cars. But it has little of the upper-level technologies that matter today to be a frontrunner, nor the mindset or the structures to quickly become a player (Dornbusch, 2000, 74).

While the intention of this study was to describe the development of European internet ventures, the approach chosen required detailed analysis of national institutional reform and firm-level resources. It was necessary to dwell on a specific European country which seemed to display a particularly strong response to the global internet opportunity. In Chapter 7, the German case is extended to other European countries.

German history is a popular subject of study for economic backwardness. Germany caught up during the Industrial Revolution and, after the destruction due to the Second World War, again regained economic strength. Although this is a subject of particularly fervent debate, part of the success of the Federal Republic after the Second World War was due to 
financial initiatives targeting SMEs, the so-called Mittelstand. ${ }^{24}$ In accordance with the Marshall Plan, so-called parapublic institutions extended credit for rebuilding businesses. Germany historically has a very strong small and medium-sized enterprise (SME) base. ${ }^{25}$ Ergas described German technology policy as 'diffusion oriented', meaning that it is primarily concerned with encouraging the spread of technology throughout the economy and especially to the smaller, export-oriented firms (1987).

Yet, by the 1980s, entrepreneurial dynamism in Germany seemed to have all but disappeared, including in the key sector of information technology. For this reason, the seeming resurrection of the Wirtschaftswunder in the late 1990s came as a surprise and was featured in the media, for example, in two memorable cover stories in the news magazine Der Spiegel. ${ }^{26}$ In no other country in Europe, including the United Kingdom, was the entrepreneurial boom surrounding the converging technologies and the internet so apparent as in Germany - in fact, it could be directly compared to what was occurring at the same time in the United States, albeit on a much smaller scale. In the year 1999 alone, German venture capital funds invested in 510 IT and communication technology companies, including 117 internet startups. ${ }^{27}$ By the year 2000, dozens of internet start-ups had been listed on the Neuer Markt. The seemingly strong reappearance of entrepreneurial activity makes Germany an especially rewarding subject of inquiry.

Yet, while Germany was exceptional in the number of listed internet companies and the apparent suddenness of this entrepreneurial activity, it was not the only country where the boom was felt. The internet was generally perceived as a cross-border phenomenon, a technology which not only enabled the worldwide exchange of goods and services, but which could serve as a global entrepreneurial platform. Should the entrepreneurial turnaround in Germany be understood as a development with mostly global origins? Or was it the result of fervent domestic institutional reform in the telecommunications sector, supported by national innovation policies promoting venture capital? The objective of this book is to explore these questions using evidence gathered directly from the new ventures themselves.

\section{COMPANY FOCUS AND EMPIRICAL RESEARCH}

A close look at the firm level is necessary to fully understand the origins of entrepreneurial revival in Europe and to explain its failure after financial downturn. The delicate linkages between firms and policy-making on a micro political economy level (Sally, 1995, 206, 207), help expose the importance of specific global and domestic determinants. Without detailed analysis, US, German and other experiences can easily be conflated into one 
universal, worldwide structural phenomenon or, alternatively, domestic developments can be cited as sole determinants.

An awareness of timing is crucial for this study. It is important not to equate the stock market bubble with the entrepreneurial wave surrounding the internet, at least not off-hand without detailed analysis. Initial entrepreneurial activity in Europe in response to converging technologies, online services and data networks clearly began before 1995 (Waesche, 1999a). Furthermore, even the first generation of European internet entrepreneurs who founded their companies around 1995 and 1996 could not have predicted the future course of the stock markets, especially the development of the Frankfurt stock exchange Neuer Markt. The Neuer Markt started only in 1997 and its first year of activity was relatively slow. The same applies to the first generation of internet start-ups in the United States, although here stock market growth was evident much earlier. 'Irrational exuberance' on the stock markets was identified in a frequently cited speech by Alan Greenspan in 1996. First generation internet start-ups in the United States were founded in 1994 and 1995. It cannot be denied, however, that strong stock market growth until consolidation in the year 2000 greatly benefited the first generation of US internet entrepreneurs. Stock market growth provided these companies with a considerable flow of funding through secondary stock offerings as well as acquisition opportunities based on high valuations. With this advantage bestowed by the capital markets, a limited number of first generation US internet companies could pioneer new, networked business models, achieve sustainability and seriously establish their presence in international markets in Europe and Asia. In order to compare first generation internet venture activity in Europe to that of the United States and other countries, the intentional choice was made to collect empirical data early, in this case, in the Spring of 1998.

But the year 1998 was also important for another reason. It was the year in which basic telecommunications services were liberalized in many European countries including Germany. The demand structure for internet services would be considerably influenced by the actions of the new regulatory agency for telecommunications in Germany operating from 1998. By analysing the innovative capabilities of internet ventures in Germany at the beginning of this crucial year, the perspective gained is that of internet entrepreneurship before the demand effects of liberalization could unfold. Demand structures changed significantly after 1998 , but by that time the competitive capabilities of the first generation of German internet ventures had already been defined. Second generation activity did not have sufficient time to develop before the downturn of the capital markets in 2000.

The challenge to this research approach was that, in 1998, there was a lack of quality information about internet ventures in Europe. At the time 
of research, Europe was still populated mostly by privately-held internet ventures. For this reason, the country case study of German internet ventures was supported by empirical research carried out together with a major German business publication. Data from over 120 German internet ventures was collected.

Despite the insight provided by this data, the conclusions that could be drawn from a single-country empirical study were to a certain extent limited. The trade-off between the level of detail provided by a singlecountry empirical study and the comparative insight of a multi-country study was apparent. To overcome the limitations of this trade-off, a brief survey of Sweden has been included in this volume, in Chapter 7.

While the key years for this study were the years from 1995 to 1998 , the full time period surveyed here extends from the 1970s, when the first corporate data networks were implemented and the internet was developed as a research network, to the beginning of 2002. In 2002, the effects of the downturn of the stock markets were evident. The period of innovation and entrepreneurial activity surrounding the internet was clearly over.

\section{CHAPTER BREAKDOWN}

The chapters of this book are arranged in the following way. The study begins with an analysis of the global internet opportunity, moves to the domestic level with a detailed examination of Germany, and ends in a European comparative overview. In this overview, internet development in Sweden is dwelled upon as a special case. Initially, the study is concerned with insight emerging from sociology and network thinking. The focus is not on specifically technological aspects or the commercialization of the internet, which have been thoroughly examined by other scholars using the US case. While this literature is addressed to provide a basis for further discussion, Chapters 2 and 3 are explicitly dedicated to the global nature of the internet opportunity. How did it arise - what were the economic and political prerequisites for the internationalization of the internet? The themes of globalization and global convergence will also be explored. Globalization was a strong social shift some researchers believe was occurring; in a specific sense it played a crucial role in the worldwide diffusion of the internet.

The first, global section serves as an entry point to the detailed study of Europe, which stands at the centre of this book. While the global internet infrastructure was being built and extended, policy-makers were at home pondering national competitiveness in a new era. Policy reform was under way. But to what extent was internet entrepreneurship driven by global or 
domestic developments? To answer the main research question, one domestic economy was selected and analysed on a micro-political and enterprise level. The following three chapters on Germany successively discuss the three main agent types in relation to the development of the German internet: the role of national government bodies, the Deutsche Telekom and the internet ventures themselves.

Chapter 4 has a dual function. It broadly describes the policy-making process in Germany. It also discusses various reform initiatives, such as research policy, including venture capital support programmes and the promotion of the national online service BTX. It focuses on the research policy shift under Christian Democrat government from a dirigist programme to an initiative emphasizing public-private partnerships and indirect financial support. Chapter 4 also has an important introductory role. It is difficult to understand the strategy of the Deutsche Telekom as an independent agent without discussing German government policy first.

In the fifth chapter, telecommunications liberalization is analysed, especially how it impacted on the demand for internet services in Germany. The chapter concentrates on the role of the Deutsche Telekom and why it was unable to act as a catalyst for the uptake of internet services in Germany. To do so, it traces the historic transformation of former postal and telecommunications ministry to the Deutsche Telekom. When DTAG was partially privatized and listed as a public company in 1996, it needed to modernize its technological base, reduce its debt burden and internationalize. The result was a large cash requirement which was served by comparatively high basic telephony tariffs as long as possible until and after liberalization in 1998. High prices restricted demand for internet access. For the purposes of this study, the period from the stock market listing in 1996 to liberalization in 1998 is critical. During this time period, Deutsche Telekom (DTAG) has to be understood as an independent agent, despite its links to German government, especially in the Finance Ministry. The objectives of DTAG were very different from those of other policy bodies, although these differences were perhaps not even understood by the policy-makers themselves.

Chapter 6 builds upon empirical research - a survey of over 120 internet start-ups in Germany - to gain a detailed look at the enterprise level. The intention was to expose forward linkages originating from telecommunications liberalization and discuss the overall impact of different policies of competitiveness, including the promotion of venture capital. In this chapter, the refraction framework, presented in the theoretical part of this introductory chapter, is put to use. A detailed analysis of the trajectory of German internet start-ups allows us to understand the strength of the refraction effect and also how it operated.

In Chapter 7, the development of internet ventures and policy conditions 
is compared with that of other European countries. In particular, Sweden stands out with its distinct path of internet development. The purpose of this section is to understand better what was learned in the one-country study of Germany and to place these learnings in an international context. The international focus at the end of the book essentially returns to the theme of the first part of the book, however, under consideration of possibly unique national characteristics. The exploration of global technological shift and a specific, institutionally conditioned domestic environment can then be concluded.

\section{WAS IT MERELY 'IRRATIONAL EXUBERANCE?'}

Before beginning with the discussion on European internet entrepreneurship, it is important to recall that the period under examination here coincided with a massive bubble on the international stock markets and with unprecedented investor interest in internet companies. From the famous Alan Greenspan warning about 'irrational exuberance' in 1996 (see Schiller, 2000) to the downturn in the year 2000 and the associated emergence of stories of 'infectious greed', the stock markets were on a continual rise, with a slight dip in 1998. Investors seemed to temporarily have believed that the world was, indeed, entering a New Economy of sorts. Public preoccupation with the stock market bubble and the subsequent loss of considerable sums of money by small investors tended to overshadow some of the underlying currents of internet development. One such important underlying current was the relationship of internet entrepreneurship to telecommunications liberalization.

One of the intentions here was to expose some of these underlying currents, an activity which seemed to the author to have shared similarities with an archaeologist scraping at a slab of ancient material to isolate some fossilized bones. At times, an archaeologist may find that the fossil he worked so hard to uncover was an insignificant, common find, not particularly beautiful and not adding to his knowledge of the era. The archaeologist can even fall victim to a hoax. Considering the amount of work involved, these were, indeed, frightening thoughts. These thoughts continually accompanied this research task.

It was crucial to consider the hypothesis that the internet opportunity may actually not have been an overly significant aspect when viewed against decades of telecommunications and information technology (IT) development. An accurate portrayal of internet entrepreneurship and innovation should, perhaps, emphasize a longer-term development of telecommunications and IT technologies with a definite leading role occupied by the 
United States. Development was continual, albeit uneven, because it was constrained to the US. This would have been the expected path for interpretations guided by institutionalist thinking. Given the excesses of the 'bubble', it seems very possible that the 'Internet Revolution', a glorious neo-Schumpeterian vision of discontinuity and global convergence, was exaggerated. The internet was inflated out of proportion by stock market interest in a number of new ventures which disappeared soon after the market downturn. This was one of the challenges the study faced. A further challenge was that the entities under study were in continual flux.

The rise of internet entrepreneurship clearly happened in unexpected places and was accompanied by a period of national policy experimentation. Network thinkers emphasized global policy convergence, stressing that governments were forced to liberalize their industries in response to a severe loss of control. In contrast, policy-makers saw themselves as catalysts of change; their active reforms were preparing their country for a new age of network competition. Pushing aside the hype, unravelling these global and domestic factors and understanding how they contributed to internet development in Europe were the intentions behind this study.

\section{NOTES}

1. Holger Schmidt, 'dot.com. Zur neuen Gründergeneration im Internet,' Frankfurter Allgemeine Zeitung, 1 January 2000, page 17 (author's translation).

2. For a review of macroeconomic implications of the 'New Economy', such as the reduction of inventory costs, see DeLong $(2000,2001)$. For the term 'business webs' see Tapscott, et al. (2000). A discussion of the real time economy including business cases can be found in The Economist: 'How about now? A survey of the real time economy.' 8 February 2002.

3. For the concept of 'disruptive technologies' and the reactions of established enterprises to new, initially inferior technologies see Christensen (1997).

4. Press release by European Information Technology Observatory (EITO), 'EITO 2001: Strong acceleration in Net Economy development expected to continue in Europe, despite present storms in capital markets. ICT market in Europe grows by 13 per cent in 2000, outdistancing US growth rate (8.2 per cent)', Brussels, 28 February 2001.

5. Over the year 2000, NASDAQ had lost 56 per cent of its value, while the Neuer Markt index, NEMAX, lost about 80 per cent. 'Falscher Glaube an eine neue Ära. Aufstieg und Fall des Neuen Marktes: Wie die Euphorie entstand und wer sie antrieb', Financial Times Deutschland, 15 March 2001, 21.

6. DG Bank Deutsche Genossenschaftsbank AG Research, 'Neuer Markt', February 2001.

7. 742 seed and start-up companies received venture capital financing in France, 354 in Sweden, 250 in the Netherlands and 123 in the United Kingdom. Figures from EVCA (2000).

8. For a critical examination of leapfrogging opportunities provided by innovation in the telecommunications industry in developing countries see Singh (1999).

9. See, for example, George Gilder's discussion of the fibre-optics venture Global Crossing (2000, 183-92) as well as his critique of US anti-trust policy $(2000,165-80)$.

10. See also the instructive German-language article on the demise of the 'New Economy' 
by Peter Glotz, 'Aus der Traum', Die Woche, 23 March 2001, 14. Also: Nicholas Garnham (2000, 63-81) and Brian Winston (1998).

11. Douglass North also downgraded the significance of the entrepreneur and innovator $(1966,8)$.

12. Excerpt from an editorial introduction to an essay on resistance to technological innovation by Joel Mokyr (Olson and Kähkönen, 2000, 12).

13. For a discussion, see Hill and Deeds (1996, 429-31).

14. See the section 'The Best of Times' in Thurow (2000, 16-22). For a short discussion about industrial research laboratories: Nelson and Rosenberg (1993, 10-11).

15. Mowery and Nelson developed the term 'sectoral innovation system' to reflect this insight (1999a, 369, 370).

16. See the classic comparison between Russia and Germany during the Industrial Revolution by Alexander Gerschenkron (1962).

17. Lawrence Lessig's exceptional book strongly and correctly emphasized agent decisions; the internet was deliberately designed to encourage innovation (2001).

18. Interestingly, this echoes yet another, theoretical debate within IPE scholarship in the United States between sociological and institutionalist accounts of change in the international economy. However, this debate is broad and has not explicitly focused on technology either. Refer to Katzenstein et al., (1999b, 30-42).

19. The economists David Mowery and Richard Nelson have dedicated a section in their recent book to the difficulties of distinguishing between resource availabilities, institutions and domestic market conditions (1999b, 5-7).

20. For a discussion of parapublic institutions see Webber $(1994,156)$.

21. For excellent research on the origins of the universal telephone system in Germany and the unique path of development of this system, refer to the work of Frank Thomas (1995).

22. It was small firms which were seen as anachronistic elements obstructive to progress which cannot afford extensive research programmes. Business historians such as Chandler showed how large firms developed powerful efficiencies of scale and scope. The political economist J. K. Galbraith in 1957 emphasized the importance of large firms in technological innovation, made possible through the deployment of additional resources for R\&D within the firm. The later Schumpeter tended to agree with this view when discussing the twentieth century (1975). Williamson used the concept of transaction costs to explain the efficiencies of large firms (see, for example, Williamson and Winter, 1992). In the global economy, the advantages of large firms were compounded. Multinational enterprises (MNEs) were linked in works on international political economy (IPE) to national governments in terms of their power and wealth. IPE has, to a great extent, been preoccupied with MNEs (Carnoy et al., 1993, 8). MNEs used their transnational structures in order to allocate their resources more effectively and cut their costs. They negotiated with governments, using their global mobility as a powerful bargaining chip. John M. Stopford, Susan Strange and John S. Henley called this 'new diplomacy' (1991). In a similar way, John H. Dunning, who has extensively studied international business and multinational firms, recognized the contributions of small firms in the global economy, but saw their activities very much as 'orchestrated' by MNEs (1993b).

23. Mowery and Nelson have argued recently that a narrow focus on industrial districts does not do justice to the variety of networks firms are linked to at different geographic levels: regional, national and global. They prefer the term 'sectoral innovation systems' (1999b, 9-10); previously, the emphasis was on national innovation systems (Nelson, 1993).

24. Werner Abelshauser disagreed that the economic foundation of Germany in terms of capital equipment and know-how was destroyed during the Second World War and therefore downplays the impact of the Marshall Plan (1983). Alan S. Milward emphasized the importance of the Marshall Plan and widened the debate to its role in having promoted European economic cooperation (1984). Christoph Buchheim discussed the role of the Marshall Plan in the development of a post-war multilateral free trade system involving Germany $(1990,99-107)$. 
25. In 1986, SMEs, defined in Germany to be firms with under 500 employees, accounted for 46 per cent or private sector GDP, compared to 32 per cent in Britain (Bannock and Albach, 1991, 56).

26. 'Hilfe gegen Arbeitslosigkeit? Erhards Enkel. Gründungs-Boom durch junge Unternehmer', Der Spiegel, 3, 13 January 1997; 'Die 68er regieren - und ihre Kinder gründen Unternehmen. Generation Ich. Von der Revolte zur Rendite', Der Spiegel, 21, 22 May 2000.

27. Statistics from the Bundesverband Deutscher Kapitalbeteiligungsgesellschaften e.V. for 1999 (dated 31 December 1999, accessible on the web site http://www.bvk-ev.de/). 